Historic, Archive Document

Do not assume content reflects current scientific knowledge, policies, or practices. 



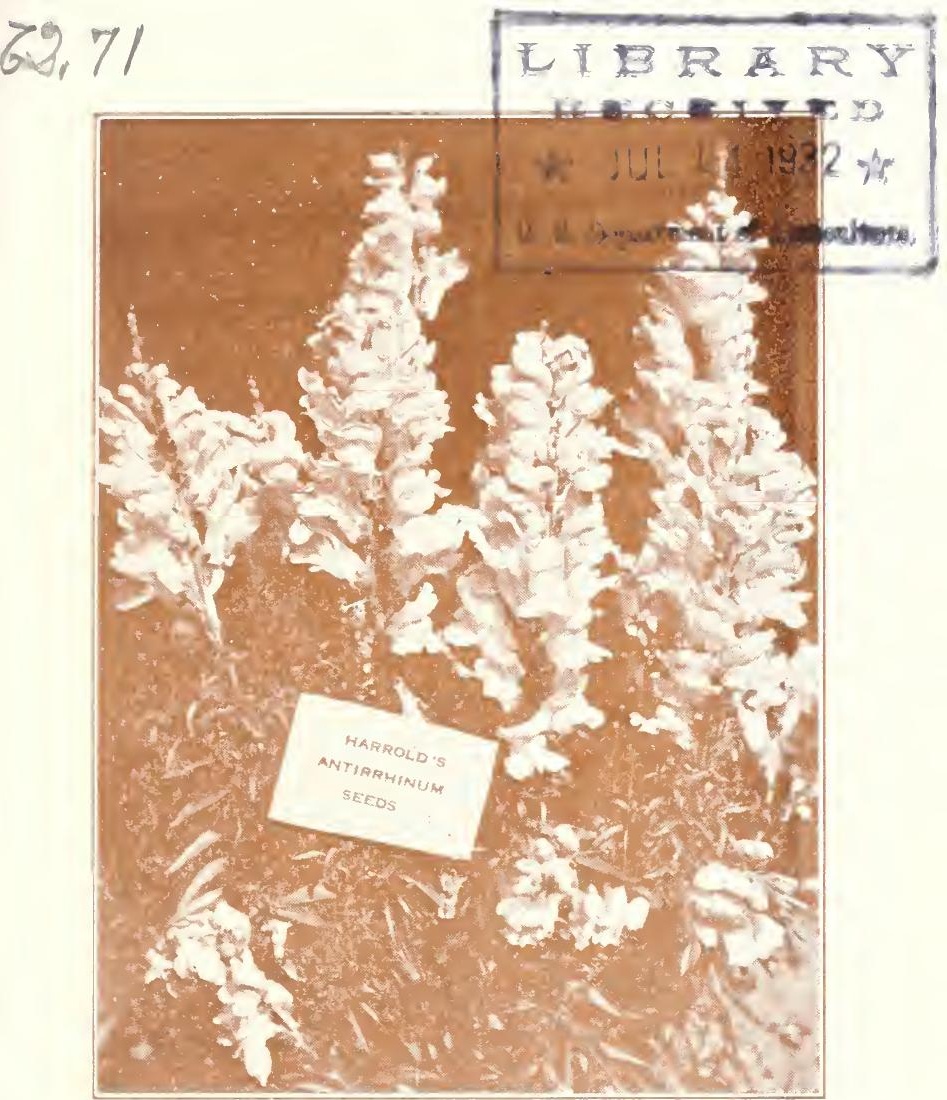

HARROLD'S

FLORIST STRAIN

\title{
SEEDS AND BULBS
}

\section{HARROLD'S}

\author{
GREENHOUSE AND BULB DEPARTMENT
}




\section{HARROLD'S FLORIST STRAIN ANTIRRHINUM SEEDS}

Our entire thought in assembling this selection of these justly popular varieties of Antirrhinum (Snapdragon) seeds, has been to supply our patrons with only the best in variety, and seeds of quality.

In the past we have offered only seeds of our own growing, but we find that owing to cultural difficulties experienced with some varieties, we can give our patrons better quality and service, on a few varieties, by obtaining these from other reliable specialists.

We are still growing over $75 \%$ of our own seeds though, and we assure you that our stock will equal in quality any that we have supplied in the past, and be superior to much stock offered.

Afterglow. Golden bronze, early and popular.

Ceylon Court. Canary-yellow. Finest early long stemmed yellow.

Cheviot Maid. Pink. Strictly the earliest pink.

Early Columbia. (Judd.) Columbia rose pink.

Early Premier. (Judd.) Premier rose pink.

Geneva Pink. Rich rose pink. Medium early.

Golden Pink Queen. Color as named.

Harrold's Red. New deep wine red, fairly early.

Helen. The standard salmon.

Jennie Schneider. Columbia Rose pink, fairly early.

Keystone. Standard pink.

Laura. Deep rose. Not very tall but early and prolific. Laurene Harrold. New; blended pink and yellow of sunset tints. Fairly early and very attractive.

Orlando. Bronze. Reasonably early and an old favorite.

Penn Orange. Extra early, tangerine orange.

Philadelphia Pink. Light rose. Medium early.

Roman Gold. Golden yellow suffused pink. Early.

Silver Pink. Light pink. Inclined to fade under heat. Sunburst Improved. Sunburst Rose color. Early. White Rock. The standard white.

Note: Our supply of Afterglow is sold up to August 20th. All other varieties are in stock at time of going to press.

\section{UNIFORM PRICES ON ALL VARIETIES}

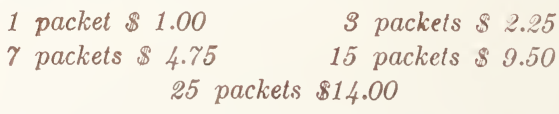

25 packets $\$ 14.00$

Antirrhinum list continued on the next page 


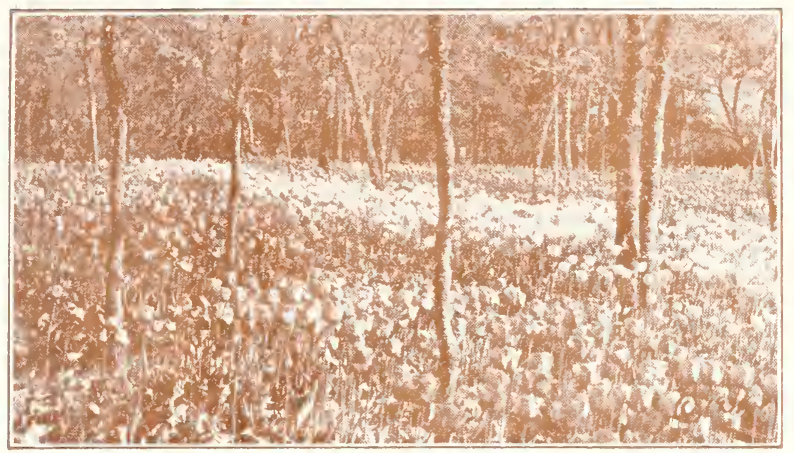

ONB OF OUR TULIP PLANTINGS

\section{ANTIRRHINUM LIST CONTINUED \\ SPECIAL ASSORTMENT FOR THE SMALL GROWER}

For the small florist we supply an assortment, consisting of $\frac{1}{6}$ packet each of any four varieties you may choose from this list, at $\$ 1.50$ per assortment. These assortments are guaranteed the same as one packet.

\section{GERMINATION GUARANTEE}

we guarantee that every packet of Snapdragon, (Antirrhinum) seeds supplied by Harrold's Greenhouses, will with usual care produce at least one thousand plants. Should for any reason they fail to do so, upon proper notification, we will replace packet for packet those failing to fulfill this guarantee FREE of charge. It is understood however, that in the event of the purchase of a number of packets of one variety, and they fail to conform to the terms of this guarantee, that replacement will be made on the aggregate and sufficient seed supplied to make up any deficiency.

It is also understood that Harrold's Greenhouses will in no case assume a responsibility greater than the original price of any stock supplied under this guarantee.

\section{CALENDULA SEEDS}

Ball Orange. This improved strain, immense in size with exceptionally thick, heavy flowers produced on very long stems. Especially recommended for culture under glass.

Ball Supreme. Light orange with brown center.

Ball Apricot. Rich apricot with darker center.

Ball Lemon Queen. A new glowing yellow darkening at center. Long stemmed, fine for cutting.

Ball Gold. Deep golden yellow. Long stemmed.

Radio. Bright orange. Medium size and deep flowers having quilled petals giving a most novel effect.

Prices: Any variety, trade packet $50 \notin ; \frac{1}{4}$ ounce $\$ 1.00$ $\frac{1}{2}$ ounce $\$ 1.60$ : 1 ounce $\$ 2.75 ; 2$ ounces $\$ 5.00 ; 4$ ounces $\$ 8.00$ per pound $\$ 20.00$. Quantity prices may be applied on assorted orders. 


\section{BULB DEPARTMENT}

The Rogue River Valley, in the vicinity of Grants Pass, has become justly famous for the high quality of the bulbs produced here. Unlike so many districts, bulb production is not confined to one or two varieties, but covers most of the popular winter bulbs, as well as Gladiolus.

Our facilities for supplying your bulb needs has been greatly expanded during the past year, and we can now supply any of the many varieties listed herein in large commercial quantity. Our supply of many varieties is very large as we have over 200 acres of cultures from which to draw our stock. A major portion of these fields we inspect regularly throughout the growing and harvest season.

Owing to the instability of prices experienced last season, we are listing here only varieties we can supply. This season we will issue a series of several price lists during the active selling season. These will enable us to keep you informed as to the most attractive price possible at all times. As these price lists will be issued only in limited editions, it is suggested that if interested you drop us a card asking that your name be put on our list to receive these bulb mailings. Or, better still, send us your want list and let us give you special direct quotations.

\section{DUTCH IRIS}

The following selections of these most popular bulbs will be found most complete, embracing the best of the commercial sorts. You will find them most profitable forcing subjects.

A. Bloemaard. Standards dark purplish blue, falls lighter blue, very large flowers, early.

D. Haring. Standards greyish white, falls pure white, large, tall, and early.

E. B. Garnier. Standards and falls uniform deep blue. The improved Imperator.

Filifolia Imperator. Dark blue, large medium early.

Hart Nibbrig. Beautiful clear blue.

Supreme. A new sensational early blue, imported from France. Released from federal control for the first time this season.

Therese Schwartz. Standards pale corn-flower blue, falls white with orange stripe. Excellent for cutting.

Yellow Queen. Standards pale yellow, falls goldenyellow, excellent forcer, the best yellow.

Wedgewood. The best large flowering early blue.

\section{LILY BULBS}

Regale. A full assortment of sizes. Also seeds.

Candidum. A full compliment of commercial sizes. 


\section{BREEDER TULIPS}

Chestnut. Dark brown.

Golden Bronze. Light brownish yellow.

Heloise. Deep red, yellow center.

Madame Le Thierry. Dark cherry rose.

Marginata. Apricot orange, yellow border.

Plutarchus. Light bronze, flushed pink.

Professor Schotel. Bright greyish violet.

Roi de Siam. Purplish violet.

Yellow Perfection. Light bronzy yellow.

\section{COTTAGE TULIPS}

Inglescombe Yellow. Glossy canary yellow.

Moonlight. Sulphur yellow.

Nectar. Crimson, pure white base.

Quaintness. Bronze, brown and orange.

\section{DARWIN TULIPS}

Bronze Queen. Bronze.

Carle Becker. Rose pink.

Clara Butt. Salmon rose. A good forcer.

Farncombe Sanders. Bright scarlet forcer.

Massachusetts. Soft rose.

Pride of Haarlem. Bright carmine forcer.

William Copeland. Bright violet forcer.

IV linam Pitt. Brilliant dark scarlet.

\section{OREGON GROWN NARCISSUS}

Campernelle Regulosus. (Jonquil). Single, rich yellow, fragrant.

Chinese Lily. Very early, excellent for water culture.

Elvira. (Poetaz.) Yellow cup, white perianth, late flowering.

Golden Spur. Uniform yellow, early, most popular forcer.

Grand Monarch. White with yellow cup, many flower's to the stem, fragrant.

aing Alfred. Uniform yellow, excellent forcing variety.

Moneymaker. (Improved Princeps.) Very free fluwering and early.

Orange Phoenix. (Double.) White with orange cente!.

Orinatus. (Poeticus.) White perianth, yellow cup rimmed red, very early.

Recurvus. (Poeticus.) (Pheasant's Eye.) White perianth cup, deep orange red.

Sea Gull. Short yellow cup, star like cream perianth.

Soliel D' Orr. (Yellow Paper White.) Yellow, orange cup, fine for forcing.

Spring Glory. (Bicolor Trumpet.) Large and early.

Van Wavern's Giant. (Bicolor.) One of the largest types. Large yellow cup, white perianth.

Von Sion. (Double.) The standard for forcing. Yellow.

\section{HYACINTHS}

Gertrude. Single dark pink. Good forcer.

L'Innocence. Single white forcer.

Bismarck. Single blue forcer. 


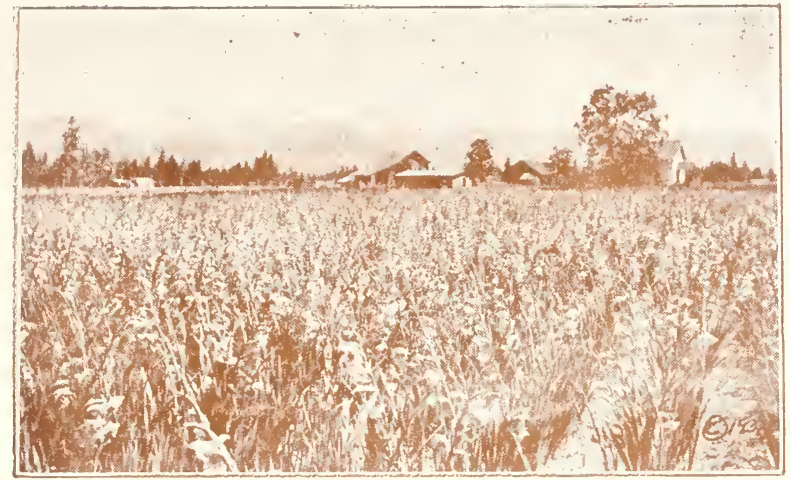

THIS IS ONE OF OUK LOCAL GLADIOLUS PLANTINGS

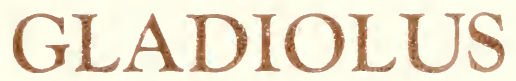

These are a great specialty with our bulb department. We can supply over one hundred varieties, ali the finest, in a complete range of commercial sizes. Our quality is always the highest, and our prices are very attractive. When interested in Gladiolus of any sort, it will pay you to give us an opportunity to quote on your want list.

\section{GLADIOLUS FOR LATE PLANTING}

This season we will have quite a quantity of the three largest sizes of Gladiolus bulbs that have been placed in storage to meet our demands for this stock in late spring, and mid-summer. With this reserve we will be ready to supply your needs for stock that may be planted as late as the last of August. This stock makes ideal bulbs for July plantings as it is all from the 1931 crop, and has been dormant song enough to develop a flower crop quickly, and completely. May we send you a list of available varietics and attraclive prices?

\section{CONIITIONS OF SAIE}

Prices as quoted are net, on a basis of cash with order. Seeds will, however, be shipped C. O. D. on request.

Remittance may be by any of the usual commercial methods, excepting that we do not accept stamps. Patrons outside the United States should remit in American funds by bank draft, or postal money order.

All Orders are received subject to supply available and crop conditions beyond our control. paid.

Shipment of seeds are made by insured post pre-

Our Responsibility: Owing to the many contingen. cies that may occur to stock after leaving our hands, shall be definitely restricted to an amount not ex. ceeding the purchase price of the goods.

Our Reference: The First National Bank of Southern Oregon, Grants Pass, Oregon, or any of the major irade journals. 